\title{
Golden Rules of Financing Related to the Life Cycle of Czech Automotive Firms
}

\author{
Konečný Zdenèke
}

\begin{abstract}
Companies go through their life cycle and it is only possible to moderate but not completely eliminate the switchover from one phase to another. Each phase is connected with different financial results as a consequence of financial conditions and financial decisions. The aim of this article is to find out whether the golden rules of financing are (or are not) respected, dependent on financial strategy, in sub-phases of the corporate life cycle. It is caused by the fact that the golden rules are indicators of the rate of financial risk and some providers can consider their respecting by deciding to lend capital. However, golden rules of financing are not set strictly and therefore the comparison with market averages is necessary. The research is implemented by analyzing secondary data from financial statements and documents of the Ministry of Industry and Trade of the Czech Republic for years from 2007 to 2011. The sample consists of 43 companies limited by guarantee and joint-stock companies, regardless their size, acting in the Czech automotive industry. Phases of the corporate life cycle are identified according to the model by Dickinson (2010) based on combinations of cash flow values. The research showed that the golden rule of risk compensation is respected especially during maturity, whilst during introduction it is broken and on the market this rule is not respected either. Almost in all companies, regardless the phase, as well as on the whole market are long-term assets financed with long-term sources. During maturity, shake-out and decline the recommended liquidity of the second level is reached, but not the liquidity of the third level, whereas during the introduction and growth is not reached the recommended liquidity of any levels. The market is characterized with a sufficient liquidity of the second and insufficient liquidity of the third level. A surprising finding is that the golden ratio rule is, in most periods, respected on the market, but not in many companies in any phases.
\end{abstract}

Key words: capital providers, corporate life cycle, financial risk, financial sources, golden rules of financing,

\section{INTRODUCTION}

All companies go through individual phases of the corporate life cycle. This fact affects especially values of quantities describing the financial health of the company. Deviations of values of these quantities, as a result of a switchover from one phase to another, can be, thanks to good management of the company, only moderated, not quite eliminated. There are some possibilities how to get it, namely innovative activities or using suitable marketing tools. But there will be never guaranteed the permanent growth, because there is necessary to consider, that the company has a limited production capacity at one's disposal and so there isn't possible to quite satisfy customers, who have ever more requirements.

An analogy to the corporate life cycle is the economic cycle. In this case, there is possible to use some tools of fiscal policy of government or monetary policy of central bank, but the con- 
sequence is only moderating deviations of economic performance. They also don't prevent the switchover from economic growth to economic decline.

The financial health of the company is determined not only by profitability, but also by liquidity and other indicators related to financial risk, which are termed as golden rules of financing. And their respecting, or not respecting, during the corporate life cycle is the main aim of this article.

\section{THEORETICAL BACKGROUND}

As there was mentioned above, during the corporate life cycle are the financial results considerably changing, which consequently influences access to external financial sources and cost of capital, because investors consider the rate of entrepreneurial risk. And furthermore, managers can, depending on these facts, change the used financial strategy.

\subsection{Financial results during the corporate life cycle}

At the beginning of the phase of introduction is the amount of sales equal to zero, because the company still didn't put its products on the market. In the phase of growth are the sales increasing convex, at the end of growth is this increase even less considerable and during the stabilization are the sales reaching the maximum and consequently, there is recorded a concave decrease of sales.

A similar course has, according to Kislingerová (2010) also the operating profit. Only difference in comparison to sales is, that in phases of introduction and decline are reached negative values, so there is recorded a loss.

Reiners (2004) mentions, that the market value of the company has a similar course, too. At the beginning of the foundation is the market value equal to zero, it consequently increases, in the phase of growth is reached a maximum and during the stabilization the market value decreases, until it reaches its zero value again.

Furthermore, according to Jenkins, Kane and Velury (2004), the market value is influenced during growth more by changes of sales than by the return, whilst during the decline of the company is the influence of return on the market value more considerable than the influence of sales and their change.

During the phase of mature and especially decline keep companies a higher rate of liquidity to be able to pay dividends to shareholders, which proves the research by Pashley and Philippatos (1990).

The cost of capital is, according to Reiners (2004), the highest at the beginning of the phase of foundation, because of a high beared risk. During the phase of foundation decreases cost of capital considerably, in the phase of growth already decreases it just mildly and during the phase of stabilization reaches the cost of capital its minimum and it is during this phase approximately constant. At the beginning of decline is recorded a rapid increase of the cost of capital, because of an increasing rate of risk. 


\subsection{Available financial sources during the corporate life cycle}

The need for capital increases at first, according to Reiners (2004), convex, then is this increase slowed down and the highest need for capital is at the end of the phase of growth or at the beginning of the phase of stabilization, and finally the need for capital decreases concave.

During the corporate life cycle has the company different possibilities, how to get external financial sources from financial markets. The list of external sources and forms of financing, depending on the corporate life cycle, is illustrated on Fig. 1.

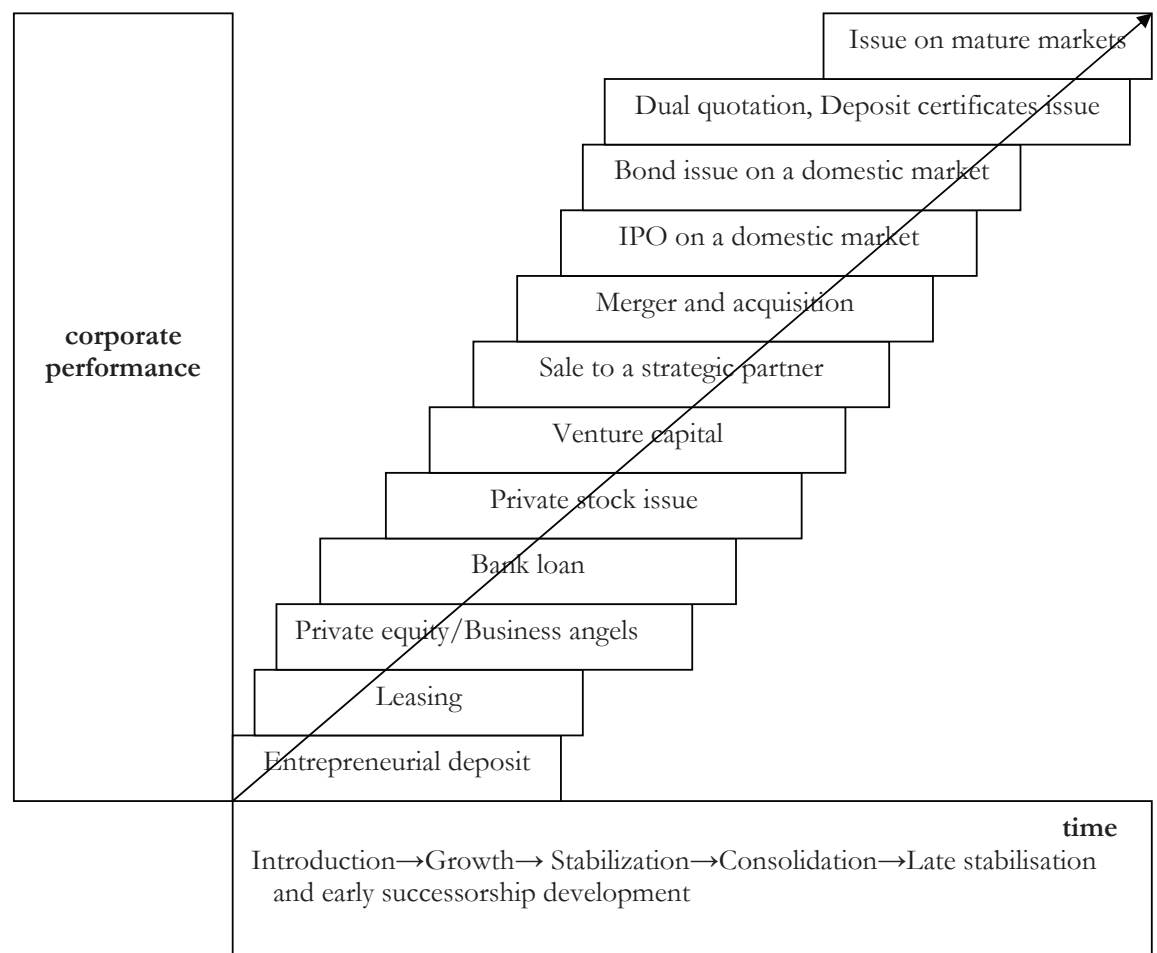

Fig. 1 - Possibilities of external financing of the company during the corporate life cycle. Source: Nývltova and Režñáková (2007).

During the introduction is the company financed almost exclusively with equity. Then, during the growth and stabilization has the company more debt available. And finally, during the decline is financing with equity dominating again, because creditors aren't willing to lend their capital and the cause is, that there is increasing the entrepreneurial risk and the probability, that the company will be overburdened with debt is, according to Reiners (2004), typical also in the phase of introduction.

Besides external sources there can be used also internal sources like depreciation, profit and longterm financial reserves, which can be termed as self-financing. Internal financial sources can be used anytime, but their amount depends on the phase of the corporate life cycle. Damodaran 
(2004) mentions, that in the phase of introduction are internal sources very low or even negative, because of a reached loss. This is valid also for an early growth, which is very rapid and is connected with large investments. During a later growth are internal sources already generated, but their amount is relative low, compared to required amount of financial sources, necessary to next investments. In the phase of stabilization are internal sources generated almost in sufficient amount to financing investments and in the phase of decline is the amount of internal sources higher than the need for financial sources, because of a decreasing number of investments.

\subsection{Financial strategies and golden rules of financing}

Financial strategy is, according to Calandro and Flynn (2007), defined as an interdisciplinary methodology to more efficiently allocate scarce resources within a firm to better or more economically satisfy customer preferences over time. This methodology consists of strategy formulation, resource allocation and performance measurement. And each of these three stages is temporally linked.

Grundy (2004) defines the financial strategy as sources, structure and mix of capital matched against a company's competitive strategy and financing needs.

Authors Randøy, Oxelheim and Stonehill (2001) comprehend the financial strategy as a selection of capital markets for an issue and a suitable financial strategy can add value to the firm, because all capital markets aren't alike and information isn't evenly distributed across nations.

According to Slater and Zwirlein (1996) should financing decisions, derived from the financial strategy, be in accordance with investing decisions and dividend decisions.

By making financial decisions there is needful to respect balance rules, termed as golden rules of financing, especially the recommendation, that long-term assets (including the long-term receivables and other lasting current assets with over one-year usability) should be financed with long-term financial sources and current assets with the short-term usability can be financed by short-term payables and short-term bank loans. According to respecting or not respecting this basic golden rule there are distinguished three types of financial strategies:

1. Aggressive strategy - there are used the short-term payables and short-term bank loans for financing the lasting current assets, or even for financing the fixed assets. Using this strategy can cause the crisis of liquidity. This type of financial strategy is suitable for companies in the phase of growth and for companies, that have guaranteed high and steady revenues in the future.

2. Moderate strategy - the lifetime of assets is in harmony with the lifetime of liabilities

3. Conservative strategy - long-term capital is used not only for financing the lasting assets, but also for financing the fluctuating part of current assets. The short-term capital is used only for financing unforeseen deviations in current assets. This type of financial strategy is most expensive but least risky and it is suitable for companies in the phase of stagnation or decline.

Besides this most important rule, termed as golden rule of financing exist also some other principles of ensuring liquidity. In this research, there are considered these four more golden rules of financing:

1. Golden rule of risk compensation - equity should be higher or at least equal to debt 
2. Golden rule one to one - short-term financial assets and receivables should be at least equal to short-term payables including short-term bank loans

3. Golden rule two to one - current assets should be at least two times higher than short-term payables including short-term bank loans

4. Golden ratio rule - rate of investments growth (calculated as the proportion of fixed assets at the end of the actual period, including the depreciation reached by the actual period, to fixed assets at the end of the last period) shouldn't be higher than the rate of sales growth (calculated as the proportion of sales for goods, own products and services reached by the actual period to these kinds of sales reached by the last period)

None of these rules is sufficient supported with theoretical considerations or practical experiences. Between the relations of assets and capital on the one side and extent of insolvency danger, which is the basic kind of financial risk, on the other side exist some connections, but there can't be proved, that a certain structure of assets can prevent the insolvency. And Bellone, Musso, Nesta and Schiavo (2010) found a main shortcoming of ratios of liquidity, which is expressed by ratios one to one and two to one. Liquidity is regarded as a sign of financial health, firms may also be forced to withhold cash by the fact that they are unable to access external funds.

Nevertheless the golden rules of financing don't miss a practical importance. According to their respecting, banks (who must respect some rules for ensuring their liquidity, too) or other creditors make decisions about lending the loan or other debt.

\section{OBJECTIVES}

The main aim of this article is to find out connections between the corporate life cycle and the used financial strategy, that is derived from respecting (or not respecting) the basic balance rule and other golden rules of financing. Then will be the results compared with last researches focused on other financial characteristics depending on the corporate life cycle. And if there will be found out some connections, there will be put some recommendations to companies, how could be changed their financial strategy to reach better financial results.

About respecting golden rules of financing during the corporate life cycle, there can be put these hypotheses:

H1: The share of equity is higher (= more than $50 \%$ of total financial sources) than the share of debt in phases of introduction, shake-out and decline, during other phases can be higher either the share of equity, or the share of debt.

H2: Long-term assets ( $=$ fixed assets + long-term receivables) are financed with long-term financial sources (equity + long-term debt) during the phase of mature and shake-out, in other phases can be this rule respected, or broken.

H3: The recommended liquidity of third level (= golden rule two to one) and second level (= golden rule one to one) is held especially during introduction, growth and mature.

H4: During the introduction is the rate of investments growth higher than the rate of sales growth, whilst during the phases of growth and mature is the rate of sales growth higher than the rate of investments growth. 


\section{METHODOLOGY}

In this article, there is used a deductive approach, because the research is based on the existing level of scientific knowledge and consequently, there will be, by using quantitative data, found out connections between variables and there will be widened existing theory on new findings.

\subsection{Used method for data collection and data processing}

There are be used exclusively the secondary data, that are analyzed. Data are gotten from financial statements of selected companies, available on the website justice.cz, and from statistical and analytical materials, published on the website by the Czech Ministry of Industry and Trade (www.mpo.cz).

For the research, there is selected the market of the czech automotive industry, which is crucial for the czech economy. In this sector is actually employed more than 110000 people, which is the most of all sectors of the czech industry. The first place holds this sector also in amount of sales, which annually reach more than 0,5 trillion czech crowns, within $60-80 \%$ comes from direct export. On the market are acting about $100-120$ medium-sized and large companies with more than 50 employees and approximately 150 small companies with the number of employees from 20 to 50 . The number of companies, who employ less than 20 people, isn't published.

The sample consists of all companies acting on this market, who met simultaneously these conditions:

1. Companies with their legal form either of company limited by guarantee, or joint-stock company

2. Companies, who publish their financial statements in the full format

3. Companies using the calendar year as the accounting period

4. Companies acting on the market continuously for all researched periods (2007-2011)

These four conditions met 43 companies in total and they are either micro and small enterprises (with the amount of assets in millions or tens of millions CZK), or medium-sized and large enterprises (with the amount of assets in hundreds of millions and billions CZK).

The main general advantages of using secondary data are especially a lower time and a lower financial difficulty. According to the focus of this article is the possibility of getting data from a sufficiently large sample of companies as the next advantage, because financial statements of most companies are published on the internet, namely on the website of BrE Companies House (www.justice.cz). Furthermore, data recorded in financial statements are relative objective and indisputable, which is one more argument for using secondary data.

As the main disadvantage of secondary data are mentioned their obsoleteness and the fact, that the original aim of their collection wasn't equal to the aim of the research, so there aren't getting tailored data. In this research, there is necessary to consider some more limitations and simplifications as follows:

1. There are published data about financial results for the whole market only on the national level, not on regional levels, and by individual companies, there are considered not only sales coming from the Czech republic, but also sales coming from other countries.

2. By calculating values of input quantities to know, whether there are respected the golden rules of financing, there are considered the items of the balance sheet ever with their amount 
at the end of the accounting period, because the financial statements are published at that moment. So there aren't considered their deviations during the year.

3. Results of the research will be valid for the selected sector of the czech economy and selected periods, the generalization will be partially possible for other sectors of the czech economy, but for multinational markets will be generalizing of results very limited, because financial statements, from which are getting the data, are subordinate to specific legislation valid for czech companies.

The data are statistically evaluated and there are used two kinds of statistical tools as follows:

1. Absolute frequencies - there is found out, how many companies in different phases of their life cycle respected the individual golden rules of financing and in how many periods was it respected on the whole market

2. Parameters of the binomial distribution - the number of companies respecting the individual golden rules of financing has a binomial distribution, because it is a discrete random variable, where founding out, if there is respected the golden rule of financing, is an attempt and the result of an attempt is independent of previous attempts

\subsection{Used method for identifying the corporate life cycle}

There are about 40 models of corporate life cycle. Their list can be found out e.g. in Rutherford, Buller and McMullen (2004), in Phelps, Adams and Bessant (2007), or in Shirokova (2009). The most important models of corporate life cycle including the variables, considered in these models, are recorded on Tab. 1:

Tab. 1 - Models of corporate life cycle and variables to identify the partial phases. Source: Shirokova (2009).

\begin{tabular}{|l|l|}
\hline Models (their authors) & Variables \\
\hline Lippitt and Schmidt (1967) & $\begin{array}{l}\text { age, management focus, different interest groups' priorities, } \\
\text { crises and presence of confrontation, sctructure, manage- } \\
\text { ment formalization }\end{array}$ \\
\hline Greiner (1972) & $\begin{array}{l}\text { age, size, industry growth rate, evolution stages, revolution } \\
\text { stages, organisation structure, formalization, top manage- } \\
\text { ment style, control system, management remuneration em- } \\
\text { phasis }\end{array}$ \\
\hline Torbert (1974) & $\begin{array}{l}\text { age, size (staff), structure, decision-making methods, man- } \\
\text { agement principles, formalization level, members of the or- } \\
\text { ganisation's individual mentalities }\end{array}$ \\
\hline Galbraith (1982) & $\begin{array}{l}\text { age, size, growth rate, objectives, structure form, staff (spe- } \\
\text { cialization), remuneration system, processes (formalization), } \\
\text { centralization, leadership style }\end{array}$ \\
\hline Quinn and Cameron (1983) & $\begin{array}{l}\text { age, size, organisation efficiency criteria, structure form, } \\
\text { formalization, centralization, leadership, culture }\end{array}$ \\
\hline
\end{tabular}




\begin{tabular}{|l|l|}
\hline Miller and Friesen (1984) & $\begin{array}{l}\text { age, number of employees, sales growth, size, property con- } \\
\text { centration, stakeholders' influence, environment dynamics, } \\
\text { strategy, Formal control, internal communications, power } \\
\text { centralization, resource capacity, differentiation, decision- } \\
\text { making style }\end{array}$ \\
\hline Schein (1985) & $\begin{array}{l}\text { culture function, management generation, complexity, size, } \\
\text { management style, top management composition }\end{array}$ \\
\hline $\begin{array}{l}\text { Smith, Mitchell and Summer } \\
\text { (1985) }\end{array}$ & $\begin{array}{l}\text { age, size (sales), size (staff), growth rate, top managers' pri- } \\
\text { orities, structure form, remuneration system, centralization, } \\
\text { top managers' interaction }\end{array}$ \\
\hline Flamholtz (1986) & $\begin{array}{l}\text { age, size, growth rate, critical development objectives, or- } \\
\text { ganisation, formalization of planning, control, budgeting, } \\
\text { operational and management systems, leadership, decision- } \\
\text { making }\end{array}$ \\
\hline Scott and Bruce (1987) & $\begin{array}{l}\text { age, size, growth rate, industry development stage, key chal- } \\
\text { lenges, structure form, control system formalization, top } \\
\text { management style }\end{array}$ \\
\hline Lester, Parnell and Carraher & $\begin{array}{l}\text { age, size, growth rate, dominating management challenges, } \\
\text { structure form, formalization, centralization }\end{array}$ \\
\hline Kazanjian (1988) & $\begin{array}{l}\text { age, size, growth rate, structure, formalization and centrali- } \\
\text { zation degree, specialization }\end{array}$ \\
\hline tion structure \\
\hline Hanks et al. (1993) & $\begin{array}{l}\text { age, size, normal and transition challenges, structure form, } \\
\text { tormalization of policies and procedures, leadership quali- } \\
\text { ties needed, diversity, complexity }\end{array}$ \\
\hline age, size, founding leader's personality
\end{tabular}

Each of these models can identify individual phases of corporate life cycle according to values, that reach variables, considered in the model. But by identifying phases there can be occurred some difficulties, following from two basic disadvantages of most models:

1. There are many variables - values of some variables can signalize one phase of the corporate life cycle, whilst values of other variables are typical for another phase, furthermore, some variables can have a greater importance by identifying phases than others

2. Some variables are qualitative factors - these variables are difficultly measurable, they can't be expressed numerically and it follows, that there isn't possible to set intervals of values for individual phases of the corporate life cycle

The applicability of most models is therefore very limited. So there were suggested easier methods of identification phases, which would consider only few variables and all of them would be quantitative factors. The best known approach is the identification phases of the corporate life cycle according to the value of cash flow. This way of identification is described e.g. in Kislingerová (2010). 
1. In the phase of foundation is the cash flow negative, because the company invests in fixed assets but these investments generate no revenues yet.

2. The phase of growth is connected with additional investments, but also with increasing revenues and depreciations. This causes, that the cash flow is positive, but not very high.

3. During the phase of stabilization is the cash flow positive and the highest, because the company doesn't have to implement additional investments (there are implemented only renewing investments) and simultaneously, the value of depreciations and the profit are still high.

4. In the phase of decline the profit decreases, which has as the consequence a decrease of cash flow, that can reach even negative values.

But the intervals of values of cash flow for individual phases don't exist, and therefore is this approach not even applicable.

There is a more elaborated approach of identification phases according to cash flow made by Dickinson (2010). In this model, there isn't considerable the absolute value of cash flow, but signs (plus or minus) of partial components, which are the cash flow from operating, investing and financial activities. The signs of these three components depending on the corporate life cycle were derived by Dickinson (2010) from these findings of previous researches:

1. Introduction - firms enter market with knowledge deficit about potential revenues and costs and so the cash flow from operating activities is negative. Managerial optimism drives investment and so companies implement early large investments to deter entry and so the cash flow from investing activities is negative, too. According to pecking order theory firms will access bank debt then equity and growth firms will issue short-term debt. The cash flow from financing activities is positive.

2. Growth - profit margins are maximized during period of greatest investment and so the cash flow from operating activities is positive. Firms make early large investments to deter entry and it follows, that the cash flow from investing activities is negative. Pecking order theory states, as the same as during the introduction, firms will access bank debt then equity and growth firms will issue short-term debt and so the cash flow from financing activities is positive.

3. Mature - efficiency is maximized through increased knowledge of operations and that has as a consequence the positive effect on cash flow from operating activities. The cash flow from investing activities is negative, because the obsolescence increases relative to new investments as firms mature. Focus shifts from acquiring financing to servicing debt and distributing excess funds to shareholders and mature firms will issue longer term debt. The cash flow from financing activities is negative.

4. Shake-out - declining growth rates lead to declining prices and routines of established firms hinder competitive flexibility, which causes, that the cash flow from operating activities can reach either positive, or negative values. About values of cash flow from investing and from financing activities still don't exist any scientific findings and so these components can in this phase reach either positive, or negative values, too.

5. Decline - Declining growth rates lead to declining prices and so the cash flow from operating activities is negative. The cash flow from investing activities is positive because of the liquidation of assets to service debt. And the cash flow from financing activities can be 
either positive, or negative, because of the focus on debt repayment and/or renegotiation of debt.

So all the combinations of signs of cash flows, from which there are, according to Dickinson (2010), identified phases of corporate life cycle are in a well arranged way illustrated on Tab. 2:

Tab. 2 - Identification corporate life cycle according to combinations of values of cash flow. Source: Dickinson (2010).

\begin{tabular}{|l|c|c|c|c|c|c|c|c|}
\hline & Introduction & Growth & Mature & \multicolumn{2}{|c|}{ Shake-out } & \multicolumn{2}{|c|}{ Decline } \\
\hline $\begin{array}{l}\text { Cash flow } \\
\text { from operating } \\
\text { activities }\end{array}$ & - & + & + & - & + & + & - & - \\
\hline $\begin{array}{l}\text { Cash flow from } \\
\text { investing activities }\end{array}$ & - & - & - & - & + & + & + & + \\
\hline $\begin{array}{l}\text { Cash flow } \\
\text { from financing } \\
\text { activities }\end{array}$ & + & + & - & - & + & - & + & - \\
\hline
\end{tabular}

This model can easily identify individual phases of corporate life cycle and its applicability is the basic argument to use it in this research. Its disadvantage is, that there isn't exactly determined, which items (or accounting operations) influence operating, investing and financing cash flow. And the second difficulty is, that in this model isn't considered the fact, that at least one component can reach its zero value. Usually the cash flow from operating and investing activities reach either a positive, or a negative value, but for cash flow from financing activities is its zero value quite frequent. And so there is necessary to add one more phase, namely growth/mature for the case of reaching a positive value of operating, a negative value of investing and the zero value of financing cash flow.

\section{RESULTS}

On Tab. 3 are mentioned all the five golden rules of financing, mentioned above, and numbers of companies depending on the corporate life cycle, regardless the period, that respected and that didn't respected them. And for comparing there are mentioned numbers of periods, when these rules were respected and weren't respected on the whole market. 
Tab. 3 - Respecting (or not respecting) golden rules of financing depending on the corporate life cycle and comparison with their respecting (or not respecting) on the whole market. Source: own research.

\begin{tabular}{|c|c|c|c|c|c|c|c|}
\hline \multirow{2}{*}{$\begin{array}{l}\text { Kind of } \\
\text { golden rule }\end{array}$} & \multicolumn{6}{|c|}{ Companies in individual phases of their life cycle } & \multirow[b]{2}{*}{ Market } \\
\hline & $\begin{array}{l}\text { Intro- } \\
\text { duction }\end{array}$ & Growth & $\begin{array}{l}\text { Growth/ } \\
\text { Mature }\end{array}$ & Mature & $\begin{array}{c}\text { Shake- } \\
\text { out }\end{array}$ & Decline & \\
\hline $\begin{array}{l}\text { Golden rule } \\
\text { of risk com- } \\
\text { pensation }\end{array}$ & $8 \sqrt{ } 23 x$ & $15 \sqrt{ } 17 X$ & $9 \sqrt{4 X}$ & $64 \sqrt{ } 45 x$ & $12 \sqrt{ } 13 \mathrm{X}$ & $2 \sqrt{ } 3 x$ & $2 \sqrt{ } 3 X$ \\
\hline $\begin{array}{l}\text { Golden rule } \\
\text { of financing }\end{array}$ & $19 \sqrt{ } 12 x$ & $16 \sqrt{ } 16 \mathrm{X}$ & $12 \sqrt{ } 1 \mathrm{X}$ & $82 \sqrt{ } 27 X$ & $22 \sqrt{ } 3 \mathrm{X}$ & $5 \sqrt{ } 0 \mathrm{X}$ & $5 \sqrt{ } 0 x$ \\
\hline $\begin{array}{l}\text { Golden rule } \\
\text { one to one }\end{array}$ & $11 \sqrt{ } 20 x$ & $11 \sqrt{ } 21 x$ & $9 \sqrt{4 X}$ & $57 \sqrt{ } 52 X$ & $14 \sqrt{ } 11 x$ & $3 \sqrt{ } 2 x$ & $4 \sqrt{ } 1 X$ \\
\hline $\begin{array}{l}\text { Golden rule } \\
\text { two to one }\end{array}$ & $7 \sqrt{ } 24 \mathrm{X}$ & $6 \sqrt{ } 26 x$ & $6 \sqrt{7 x}$ & $40 \sqrt{69 X}$ & $11 \sqrt{ } 14 \mathrm{X}$ & $2 \sqrt{ } 3 x$ & $0 \sqrt{5 x}$ \\
\hline $\begin{array}{c}\text { Golden } \\
\text { ratio rule }\end{array}$ & $14 \sqrt{ } 17 \mathrm{X}$ & $9 \sqrt{ } 23 x$ & $7 \sqrt{6 x}$ & $32 \sqrt{ } 77 x$ & $9 \sqrt{ } 16 \mathrm{X}$ & $2 \sqrt{ } 3 X$ & $4 \sqrt{ } 1 x$ \\
\hline
\end{tabular}

Explanatory notes:

$\sqrt{ }$ : the rule is respected

$\mathrm{X}$ : the rule isn't respected

For considering the potential differences between results on the sample and results on the whole market, there was used the binomial distribution of probability on numbers of companies respecting the golden rules of financing, as there was mentioned above. So there were calculated the mean $\mathrm{E}(\mathrm{X})$, the variance $\mathrm{D}(\mathrm{X})$ and its square root (the standard deviation) of this binomial distribution for each golden rule of financing and there was considered, if the whole market respected $(\sqrt{ })$ or didn't respected $(\mathrm{X})$ these golden rules of financing in selected periods. These statistical characteristics are illustrated on Tab. 4. The probability of respecting the golden rules of financing (p) is calculated as the share of numbers of companies within the sample respecting them to 43 , which is the total number of companies in the sample. As the number of companies acting on the market (n), there is for each period considered a number of companies with 20 or more employees.

And as an addition to the Tab. 4, there are compared the results about respecting the golden rules of financing on the market, mentioned on the last column of the Tab. 3, with the results about respecting these rules by companies, regardless the phase of their life cycle and the period. This comparison is illustrated on Tab. 5 . 
Tab. 4 - Statistical characteristics of binomial distribution for number of companies respecting golden rules of financing. Source: own research.

\begin{tabular}{|c|c|c|c|c|c|c|}
\hline $\begin{array}{l}\text { Kind of } \\
\text { golden rule }\end{array}$ & Statistical characteristics & 2007 & 2008 & 2009 & 2010 & 2011 \\
\hline \multirow{6}{*}{$\begin{array}{l}\text { Golden rule } \\
\text { of risk } \\
\text { compensation }\end{array}$} & $\mathrm{n}$ (number of companies on the market) & 261 & 273 & 278 & 267 & 265 \\
\hline & $\mathrm{p}$ (probability of respecting the rule) & 0,56 & 0,47 & 0,49 & 0,56 & 0,49 \\
\hline & $E(X)=n^{*} p$ & 146 & 127 & 136 & 149 & 129 \\
\hline & $D(X)=n * p *(1-p)$ & 64 & 68 & 69 & 66 & 66 \\
\hline & $\sqrt{D(X)}$ & 8,00 & 8,25 & 8,31 & 8,12 & 8,12 \\
\hline & respecting the rule on the market & $\sqrt{ }$ & $\sqrt{ }$ & $\mathrm{X}$ & $\mathrm{X}$ & $\mathrm{x}$ \\
\hline \multirow{6}{*}{$\begin{array}{l}\text { Golden rule } \\
\text { of financing }\end{array}$} & $\mathrm{n}$ (number of companies on the market) & 261 & 273 & 278 & 267 & 265 \\
\hline & $\mathrm{p}$ (probability of respecting the rule) & 0,79 & 0,63 & 0,63 & 0,77 & 0,81 \\
\hline & $E(X)=n * p$ & 206 & 171 & 175 & 205 & 216 \\
\hline & $D(X)=n^{*} p^{*}(1-p)$ & 43 & 64 & 65 & 48 & 40 \\
\hline & $\sqrt{D(X)}$ & 6,56 & 8,00 & 8,06 & 6,93 & 6,32 \\
\hline & respecting the rule on the market & $\sqrt{ }$ & $\sqrt{ }$ & $\sqrt{ }$ & $\sqrt{ }$ & $\sqrt{ }$ \\
\hline \multirow{6}{*}{$\begin{array}{l}\text { Golden rule } \\
\text { one to one }\end{array}$} & $\mathrm{n}$ (number of compani & 261 & 273 & 278 & 267 & 265 \\
\hline & $\mathrm{p}$ (probability of respecting the rule) & 0,44 & 0,42 & 0,49 & 0,56 & 0,53 \\
\hline & $E(X)=n^{*} p$ & 115 & 114 & 136 & 149 & 142 \\
\hline & $D(X)=n^{*} p *(1-p)$ & 64 & 66 & 69 & 66 & 66 \\
\hline & $\sqrt{D(X)}$ & 8,00 & 8,12 & 8,31 & 8,12 & 8,12 \\
\hline & respecting the rule on the market & $\sqrt{ }$ & $\mathrm{x}$ & $\sqrt{ }$ & $\sqrt{ }$ & $\sqrt{ }$ \\
\hline \multirow{6}{*}{$\begin{array}{l}\text { Golden rule } \\
\text { two to one }\end{array}$} & $\mathrm{n}$ (number of companies on the market) & 261 & 273 & 278 & 267 & 265 \\
\hline & $\mathrm{p}$ (probability of respecting the rule) & 0,37 & 0,30 & 0,37 & 0,33 & 0,30 \\
\hline & $E(X)=n^{*} p$ & 97 & 83 & 103 & 87 & 80 \\
\hline & $D(X)=n^{*} p *(1-p)$ & 61 & 58 & 65 & 59 & 56 \\
\hline & $\sqrt{D(X)}$ & 7,81 & 7,62 & 8,06 & 7,68 & 7,48 \\
\hline & specting the rule on the market & $\mathrm{X}$ & $\mathrm{X}$ & $\mathrm{X}$ & $\mathrm{X}$ & $\mathrm{X}$ \\
\hline \multirow{6}{*}{$\begin{array}{l}\text { Golden ratio } \\
\text { rule }\end{array}$} & n (number of companic & 261 & 273 & 278 & 267 & 265 \\
\hline & p (probability of respecting the rule) & 0,40 & 0,07 & 0,14 & 0,65 & 0,44 \\
\hline & $E(X)=n^{*} p$ & 103 & 19 & 39 & 174 & 117 \\
\hline & $D(X)=n^{*} p *(1-p)$ & 62 & 18 & 33 & 61 & 65 \\
\hline & $\sqrt{D(X)}$ & 7,87 & 4,24 & 5,74 & 7,81 & 8,06 \\
\hline & respecting the rule on the market & $\sqrt{ }$ & $\mathrm{X}$ & $\sqrt{ }$ & $\sqrt{ }$ & $\sqrt{ }$ \\
\hline
\end{tabular}

Tab. 5 - Comparing probability of respecting golden rules of financing by companies within the sample, regardless the period and phase of their life cycle, and by the whole market. Source: own research.

\begin{tabular}{|l|c|c|}
\hline Kind of golden rule & Sample of companies & Market \\
\hline Golden rule of risk compensation & 0,51 & 0,40 \\
\hline Golden rule of financing & 0,73 & 1,00 \\
\hline Golden rule one to one & 0,49 & 0,80 \\
\hline Golden rule two to one & 0,33 & 0,00 \\
\hline Golden ratio rule & 0,34 & 0,80 \\
\hline
\end{tabular}




\section{DISCUSSION}

The golden rule of risk compensation is almost in all phases of the corporate life cycle broken and that is valid also for the whole market. The fact, that the share of debt is higher than the share of equity, is characteristic especially for the phase of introduction. There are two exceptions, when this rule is respected, namely during the phases of growth/mature and mature. This finding is inconsistent with some previous researches. And there was found out, that for the years 2008 and 2010 the results for the sample don't correspond with results for the whole market, but the differences are not so high, because in all years was respected this rule approximately in $50 \%$ of companies. The hypothesis H1 is rejected.

The basic golden rule of financing, that long-term assets should be financed with long-term financial sources, is respected almost in all companies, regardless the phase of their life cycle, and also on the whole market. So most of the companies use a moderate financial strategy and don't change it depending on the corporate life cycle. The hypothesis $\mathrm{H} 2$ is accepted.

The golden rule one to one, which recommends the required value of liquidity of the second lev$\mathrm{el}$, is respected during mature, shake-out and decline, but in phases of introduction and growth is the liquidity of the second level lower than required. On the whole market is the rule one to one respected in almost all periods (with one exception) and in two years, there is recorded a mild inconsistency between the sample and the market. But the golden rule two to one, which recommends the required value of liquidity of the third level isn't respected neither in companies, regardless the phase of the corporate life cycle, nor on the whole market. The hypothesis $\mathrm{H} 3$ is rejected.

The golden ratio rule, that the rate of investments growth shouldn't be higher than the rate of sales growth, is respected only during the phase of growth/mature. But for the whole market is respecting this rule typical, because only in one period was the rate of investments growth higher than the rate of sales growth, which is the most surprising finding. So in some years, namely in 2007, 2009 and 2011, there were found out some differences between results for the whole market and for the sample of companies and the highest inconsistency was recorded in 2009, when only 39 from 278 companies respected the golden ratio rule and simultaneously this rule was respected on the whole market. The hypothesis $\mathrm{H} 4$ is partially accepted.

From these results, there can be derived some recommendations to companies in different phases of their life cycle. During the phase of introduction should companies hold the liquidity of third and second level at least on the recommended values, which can be reached either by decreasing the short-term payables and short-term bank loans, or by increasing the current assets, especially short-term financial assets and short-term receivables. Companies during phases of growth and growth/mature should use a more aggressive financial strategy, so they can use short-term payables and short-term bank loans for financing the lasting current assets (or at least a part of lasting current assets), because these companies have guaranteed a sufficient amount of sales and cash flow into the future, and so the rate of financial risk isn't so high. And finally, companies during phases of shake-out and decline shouldn't implement any additional investments, because the sales will anyway rapidly decline, so these phases should be characterized rather as the periods of harvesting. 


\section{CONCLUSION}

This article was aimed at the golden rules of financing and their respecting during the corporate life cycle. After finding out, whether the rules are, or aren't respected, there can be derived, which kind of financial strategy is used in companies and how to change it to get better financial results. The research was implemented by using the deductive approach. There were used secondary data, which were gotten from financial statements of selected companies and from documents published by the Czech Ministry of Industry and Trade. After collecting the data, there was implemented their analysis. For the research, there were selected companies from the czech automotive industry. The sample consists of 43 companies limited by guarantee and joint stock companies, regardless their size, acting on the market continuously from 2007 to 2011. For identifying phases of the corporate life cycle, there was used the model by Dickinson (2010), based on combination of values, that reach cash flow from operating, investing and financial activities. There was added one more phase, namely the phase of growth/mature, because of the case, that the cash flow from financing activities can reach its zero value. From the results, there can be derived, that almost in all phases, except the growth/mature and mature, is the share of debt higher than the share of equity and this golden rule of risk compensation is broken also by the whole market. On the contrary the golden rule, that the long-term assets should be financed with long-term sources, is respected almost in all companies, regardless the phase, and on the market, too. The golden rule termed as one to one is respected on the market and also in companies during some phases, namely phases of mature, shake-out and decline, but the golden rule two to one isn't respected neither by companies in any phases, nor by the market. Respecting the golden ratio rule, according to that the rate of investments growth shouldn't be higher than the rate of sales growth, is for the whole market characteristic, but in companies within the sample is it respected only during the phase of growth/mature. From these findings can be derived recommendations, that companies during introduction should heighten the liquidity of third and second level, companies during growth and mature should use a more aggressive financial strategy and companies in phases of shake-out and decline should less invest and more harvest.

\section{References}

1. Bellone, F., Musso, P., Nesta, L., \& Schiavo, S. (2010). Financial Constraints and Firm Export Behaviour. The World Economy, 33(3), 347-373. http://dx.doi.org/10.1111/j.14679701.2010.01259.x

2. Calandro, J., \& Flynn, R. (2007). On Financial Strategy. Business Strategies Series, 8(6), 409417. http://dx.doi.org/10.1108/17515630710684628

3. Damodaran, A. (2004). Applied Corporate Finance. USA Hoboken: Wiley John.

4. Dickinson, V. (2011). Cash flow patterns as a proxy for firm life cycle. The Accounting Review, 86(6), 1969-1994. http://dx.doi.org/10.2308/accr-10130

5. Grundy, T. (2004). Strategy and financial management in the football industry. Strategic Change, 13(8), 405-422. http://dx.doi.org/10.1002/jsc.696

6. Jenkins, D. S., Kane, G. D. \& Velury, U. (2004). The impact of the corporate life-cycle on the value-relevance of disaggregated earnings components. Review of Accounting \& Finance, 3(4), 5-20. http://dx.doi.org/10.1108/eb043411 
7. Kislingerová, E. et al. (2010). Manažerské finance. Praha: C. H. Beck.

8. Nývltová, R., \& Režñáková, M. (2007). Mezinárodní kapitálové trby. Zdroj financování. Praha: Grada Publishing.

9. Pashley, M. M., \& Philippatos, G. C. (1990). Voluntary divestitures and corporate life-cycle: some empirical evidence. Applied Economics, 22(9), 1181-1196. http://dx.doi.org/10.1080/000 36849000000038

10. Phelps, R., Adams, R., \& Bessant, J. (2007). Life cycles of growing organizations: A review with implications for knowledge and learning. International Journal of Management Reviews, 9(1), 1-30. http://dx.doi.org/10.1111/j.1468-2370.2007.00200.x

11. Randøy, T., Oxelheim, L., \& Stonehill, A. (2001). Corporate financial strategies for Global Competitiveness. European Management Journal, 19(6), 659-669. http://dx.doi.org/10.1016/ S0263-2373(01)00091-3

12. Reiners, M. (2004). Finanzierungskosten im Lebenszyklus der Unternehmung. Ein optionspreistheoretis cher Ansatæ: Hamburg: Verlag.

13. Rutherford, M. W., Buller, P. F., \& McMullen, P. R. (2003). Human resource management problems over the life cycle of small to medium-sized firms. Human Resource Management, 42(4), 321-335. http://dx.doi.org/10.1002/hrm.10093

14. Shirokova, G. (2009). Organisational life-cycle. The characteristics of developmental stages in Russian companies created from scratch. Journal for East European Management Studies, 14(1), 65-85.

15. Slater, S. F., \& Zwirlein, T. J. (1996). The structure of financial strategy: Patterns in financial decision making. Managerial and decision economics, 17(3), 253-266. http://dx.doi. org/10.1002/(SICI)1099-1468(199605)

\section{Contact information}

Ing. Zdeněk Konečný

Brno University of Technology, Faculty of Business and Management

Kolejni 2906/4, 61200 Brno, Czech Republic

Email:konecnyz@fbm.vutbr.cz.

JEL Classification: G32 